\title{
ANALISIS FAKTOR YANG BERHUBUNGAN DENGAN KEJADIAN KETUBAN PECAH DINI DI RUMAH SAKIT UMUM DAERAH DR. ADJIDARMO KABUPATEN LEBAK TAHUN 2013
}

\author{
*Omo Sutomo, *Kadar Kuswandi
}

\begin{abstract}
Abstrak
Penelitian ini merupakan penelitian kuantitatif dengan pendekatan case control bertujuan untuk memperoleh informasi tentang Factor-Faktor yang Berhubungan Dengan Kejadian Ketuban Pecah Dini di Rumah Sakit Umum Daerah Dr. Adjidarmo Kabupaten Lebak tahun 2013.

Populasi penelitian ini adalah seluruh ibu bersalin di Rumah Sakit Umum Daerah Dr. Adjidarmo Kabupaten Lebak periode Januari sampai dengan Desember 2013 berjumlah 4.328 orang ibu bersalin. Sedangkan yang menjadi sampel penelitian berjumlah 1036 orang ibu bersalin yakni 518 kelompok kasus dan 518 kelompok control; dengan demikian pengambilan sampel ini dengan menggunakan perbandingan 1:1 tidak berpasangan.

Pengumpulan data dilakukan dengan cara menelaah data skunder pada buku register ibu hamil di ruang bersalin, dengan menggunakan format pengumpulan data yang disesuaikan dengan variabel yang diperlukan. Pengolahan data dilakukan dengan bantuan perangkat komputer. Analisis yang dilakukan adalah analisis univariat dan analisis bivariat dengan menggunakan uji Chi Square

Hasil analisis diperoleh bahwa kejadian ketuban pecah dini (KPD) dari seluruh ibu bersalin sebanyak 12,0\%. Sebagian besar $(55,2 \%)$ ibu bersalin berusia $\leq 27$ tahun, lebih dari separuh ibu bersalin $(51,4 \%)$ memiliki paritas primipara, masih terdapat sebagian kecil ibu bersalin $(10,4 \%)$ memiliki pekerjaan tetap, sebagian besar suami ibu bersalin $(61,1 \%)$ bekerja sebagai buruh/tani/sopir/ojeg. Dari hsil analisis bivariat diperoleh bahwa variable umur dan paritas ibu memiliki hubungan bermakna dengan kejadian KPD; dengan masing-masing nilai $\mathrm{p}=0,000$; sedangkan untuk variable umur kehamilan, pekerjaan ibu dan pekerjaan suami ibu tidak memiliki hubungan bermakna dengan kejadian KPD; dengan masing-masing nilai $\mathrm{p}>0,05(\mathrm{p}>\alpha)$.

Dari hasil penelitian tersebut diharapkan dapat dijadikan sebagai bahan acuan dalam membuat kebijakan terutama dalam pengelolan persalinan untuk mencegah terjadinya KPD. Disamping itu, perlu pula diamati hubungan trauma dengan kejadian KPD.
\end{abstract}

Kata Kunci: Ketuban Pecah Dini

*Poltekkes Kemenkes Banten 


\section{Pendahuluan}

Ketuban pecah dini (KPD) atau ketuban pecah sebelum waktunya diartikan sebagai pecahnya ketuban sebelum waktunya melahirkan. Hal ini dapat terjadi pada kehamilan aterm maupun preterm

(Prawiroharjo, 2010).Masalah KPD berkaitan dengan keluarnya cairan berupa airair dari vagina setelah kehamilan berusia 22 minggu, ketuban dinyatakan pecah jika terjadi sebelum proses persalinan berlangusng dan pecahnya selaput ketuban dapat terjadi pada kehamilan preterm sebelum kehamilan 37 minggu maupun kehamilan aterm (Saifudin, 2010). Meskipun factor penyebab terjadinya KPD masih sulit diketahui, namum beberapa factor predisposisi yang dapat diidentifikasi penyebab KPD ialah infeksi, golongan darah ibu dan anak tidak sesuai, multigrafida, merokok, defisiensi gizi khususnya vitamin $\mathrm{C}$, servik yang tidak inkopeten, polihidramnion, riwayat KPD sebelumny, kelainan selaput ketuban, tekanan intra uterin yang meninggi atau overdistesi, trauma, kelainan letak (Nugroho, 2010)

Insiden KPD bervariasi, pada kehamilan aterm insidenya antara 1$19 \%$, sedangkan pada kehamilan aterm insidenya sebesar $2 \%$ dari semua kehamilan. Varney (2008) menyebutkan insiden KPD berkisar antara 2,7 \% - $17 \%$. Sualma (2009) menyebutkan bahwa hampir semua KPD pada kehamilan preterm akan lahir sebelum aterm atau persalinan akan terjadi dalam satu minggu setelah selaput ketuban pecah dini. Sekitar $85 \%$ morbiditas dan mortalitas perinatal disebabkan oleh prematuritas. KPD berhubungan dengan penyebab terjadinya prematuritas dengan inseiden 3040\%. Insiden KPD lebih tinggi pada wanita dengan serviks inkopenten, polihidromnion, malpresentasi janin, kehamilan kembar atau infeksi vagina/serviks (missal, vaginosis bacterial, trikomonas, klamidia, gonore, streptokokus Grup B). Hubungan yang siginfikan juga telah ditemukan antara keletihan bekerja dan peningkatan risiko KPD sebelum 
cukup bulan diantara wanita nulipara (Varney, 2008).

\section{Diagnosis KPD ditegakan} dengan memperhatikan data hasil pengkajian terhadap riwayat klien seperti jumlah cairan nyang hilang karena keluarnya sedikit cairan terus menerus dan perasaan basah pada celana dalamnya. Ketidakmampuan mengendalikan kebocoran dengan latihan Kegel, waktu terjadi pecah ketuban, warna dan bau cairan serta hubungan seksual terakhir dapat digunakan sebagai data untuk diagnosis KPD. Disamping itu pemeriksaan fisik dengan melakukan palpasi abdomen, pemeriksaan speculum steril serta uji laboratorium (uji pakis positif, uji kertas nitrizin positif, dan pemeriksaan specimen untuk kultur streptokokus Grup B) dapat membantu diagnosis KPD.

Berdasarkan catatan rekam medis RSUD Dr. djidarmo Kabupaten Lebak, pada tahun 2013 kasus KPD berjumlah 241 kasus dari 4. 023 kasus $(5,99 \%)$. Kondisi ini tentu memprihatinkan mengingat KPD berdampak pada status kesehatan ibu dan bayi dan karenanya perlu upaya yang memadai untuk memungkinkan calon ibu memiliki pengertian dan pemahaman yang memadai akan pentingnya kesehatan ibu hamil untuk keselamatan kesehatan persalinan ibu dan kesehatan bayi.

Tujuan penelitian ini adalah diperolehnya informasi faktor-faktor yang berhubungan dengan kejadian ketuban pecah dini di Rumah Sakit Umum Daerah Dr. Adjidarmo Lebak Tahun 201, sehingga hasil penelitian ini dapat dijadikan sebagai bahan untuk pengambilan kebijakan, khususnya dalam penyusunan SOP tentang tanggap pencegahan dan penanggulangan/penatalaksanaan ibu bersalin yang mengalami ketuban pecah dini yang berkaitan dengan variable yang diteliti, sehingga tidak terjadi komplikasi persalinan.

Disamping itu, dengan adanya penelitian ini dapat diketahui kelengkapan data dalam buku register yang berkaitan dengan ibu bersalin, sehingga RSUD memperoleh masukkan untuk kelengkapan data yang harus ada dalam buku register ibu bersalin. 


\section{Metodologi Penelitian}

Penelitian ini dilakukan di Ruang bersalin Rumah Sakit Umum Daerah Dr. Adjidarmo Rangkasbitung - Lebak pada Bulan Juli - Agustus 2014, dengan menggunakan desain case control pada kasus ketuban pecah dini di Rumah Sakit Umum Daerah Dr. Adjidarmo Kebupaten Lebak Tahun 2013

Instrumen penelitian yang digunakan berupa format yang disusun oleh peneliti, dan disesuaikan dengan variable yang menjadi focus penelitian. Disamping itu, karena menggunakan data skunder, maka peneliti juga menggunakan buku register ibu bersalin yang ada di ruang bersalin Rumah Sakit Umum Daerah Dr. Adjidarmo Lebak tahun 2013

Populasi dalam penelitian ini adalah seluruh ibu bersalin yang terdaftar di buku register ibu bersalin ruang bersalin Rumah Sakit Umum Daerah Dr. Adjidarmo Kabupaten Lebak pada tahun 2013 yaitu berjumlah 4.328 orang. Sampel dalam penelitian ini berjulah 1036 orang yang terdiri dari 518 kasus (seluruh kasus diambil sebagai sampel) dengan perbandingan 1:1; dengan demikian kelompok control diambil sejumlah 518 dengan cara acak sederhana (simple random sampling)

Pengumpulan data dilaksanakan langsung oleh peneliti, dengan menelaah catatan/data yang ada pada buku register ibu bersalin di Ruang bersalin Rumah Sakit Umum Daerah Dr. Adjidarmo Rangkasbitung-Lebak periode bulan Januari sampai Desember 2013. Data yang dikumpulkan sesuai dengan variabel yang menjadi focus penelitian, yaitu data tentang kejadian KPD, umur ibu, umur kehamilan, paritas, pekerjaan ibu, dan pekerjan suami. Data disalin dari buku register ibu bersalin ke dalam format yang telah disusun, untuk selanjutnya dilakukan pengelolaan dan analisis data dengan menggunakan perangkat lunak dalam computer.

$$
\begin{aligned}
& \text { Data yang terkumpul } \\
& \text { dilakukan pengelolaan dengan } \\
& \text { bantuan perangkat lunak dalam } \\
& \text { computer, dengan tahap-tahap ; } \\
& \text { editing, coding, entrying, dan }
\end{aligned}
$$


cleaning. Analisis data dilakukan melalui dua tahap yaitu analisis univariat dan analisis bivariat.

Analisis univariat bertujuan untuk menggambarkan distribusi frekuensi masing-masing kategori variabel yang diteliti, sedangkan analisis bivariat bertujuan untuk melihat hubungan antara variabel independen dan variabel dependen. Uji statistic yang digunakan adalah uji Chi Square dengan batas kemaknaan pada alpa 0,05.

\section{Hasil Penelitian}

Hasil penelitian ini disajikan dalam bentuk table yang terdiri dari sajian hasil analisis pada masingmasing variable secara deskriptif yang akan mendeskripsikan hasil penelitian secara proporsi pada masing-masing kategori variable; dan sajian hasil analisis hubungan antar variable yang merupakan sajian hasil uji hipotesis, yang akan menyajikan deskripsi proporsi masing-masing kategori variable dalam table silang, nilai $\mathrm{p}$ yang menggambarkan hubungan antar variable, dan nilai OR sebagai gambaran risiko pada variable tertentu.

\section{Hasil Univariat}

1. Kejadian Ketuban Pecah Dini pada Ibu Bersalin

Tabel 1

Distribusi Frekuensi Ibu Bersalin Berdasarkan Kejadian Ketuban Pecah Dini (KPD)

Di RSUD Dr. Adjidarmo Rangkasbitung Tahun

\begin{tabular}{ccc} 
& 2013 & \\
\hline KPD & Frek & Persen (\%) \\
& & 12,0 \\
Ya & 518 & 88,0 \\
\hline Tidak & 3.810 & 100,0
\end{tabular}

Tabel 1 menunjukkan bahwa masih banyak $(12,0 \%)$ terdapat ibu beralin yang mengalami ketuban pecah dini (KPD)

\section{Umur Ibu Bersalin} Tabel 2

Distribusi Frekuensi Ibu Bersalin Berdasarkan Umur di R. Bersalin RSUD Dr. Adjidarmo Rangkasbitung Tahun 2013

\begin{tabular}{ccc}
\hline Umur & Frek & Persen (\%) \\
\hline$\leq 27$ tahun & 572 & 55,2 \\
$>27$ tahun & 464 & 44,8 \\
\hline Jumlah & 1036 & 100,0
\end{tabular}

Tabel 2 menunjukkan bahwa lebih dari sebagian $(55,2 \%)$ ibu bersalin 
berusia kurang atau sama dengan 27

tahun.

\section{Umur Kehamilan Ibu Bersalin}

Tabel 3

Distribusi Frekuensi Ibu Bersalin

Berdasarkan Umur Kehamilan di R. Bersalin RSUD Dr. Adjidarmo Rangkasbitung

\begin{tabular}{ccc}
\multicolumn{3}{c}{ Tahun 2013 } \\
\hline Umur & Frek & Persen (\%) \\
\hline Tdk Aterm & 253 & 24,4 \\
Aterm & 783 & 75,6 \\
\hline Jumlah & 1036 & 100,0
\end{tabular}

Tabel 3 menunjukkan bahwa masih banyak $(24,4 \%)$ ibu bersalin yang usia kehamilannnya tidak aterm (belum cukup bulan).

\section{Paritas Ibu Bersalin}

Tabel 4

Distribusi Frekuensi Ibu Bersalin Berdasarkan Paritas di R. Bersalin RSUD Dr. Adjidarmo Rangkasbitung

\begin{tabular}{ccc}
\multicolumn{3}{c}{ Tahun 2013 } \\
\hline Paritas & Frek & $\begin{array}{c}\text { Persen } \\
(\%)\end{array}$ \\
\hline Primipara & 533 & 51,4 \\
Multi/Grandemultipara & 503 & 48,6 \\
\hline Jumlah & 1036 & 100,0
\end{tabular}

Tabel 4 menunjukkan bahwa lebih dari sebagian $(51,4 \%)$ ibu bersalin merupakan ibu primipara (yang pertama kali melahirkan).

\section{Pekerjaan Ibu Bersalin}

Tabel 5

Distribusi Frekuensi Ibu Bersalin Berdasarkan Pekerjaan Ibu di R. Bersalin RSUD Dr. Adjidarmo Rangkasbitung Tahun 2013

\begin{tabular}{ccc} 
& Tahun 2013 & \\
\hline Bekerja & Frek & Persen (\%) \\
& & 10,4 \\
Ya & 108 & 89,6 \\
\hline Tidak & 928 & 100,0 \\
\hline Jumlah & 1036 & \\
\hline
\end{tabular}

Tabel 5 menunjukkan bahwa masih terdapat sebagian kecil $(10,4 \%)$ ibu hamil yang bekerja.

\section{Pekerjaan Suami Ibu Bersalin}

Tabel 6

Distribusi Frekuensi Ibu Bersalin Berdasarkan Pekerjaan Suami di R. Bersalin RSUD Dr. Adjidarmo Rangkasbitung Tahun 2013

\begin{tabular}{ccc}
\hline Pekerjaan & Frek & $\begin{array}{c}\text { Persen } \\
(\%)\end{array}$ \\
\hline Buruh/Tani/dagang/sopir & 633 & 61,1 \\
Bukan Buruh & 403 & 38,9 \\
\hline Jumlah & 1036 & 100,0 \\
\hline
\end{tabular}

Tabel 6 menunjukkan bahwa lebih dari sebagian $(61,1 \%)$ suami ibu hamil bekerja sebagai buruh/tani/dagang/sopir/ojeg bahkan tidak bekerja. 


\section{Analisis Bivariat}

1. Umur dan Kejadian KPD pada Ibu Bersalin

Tabel 7

Distribusi Frekuensi Ibu Hamil Berdasarkan Umur dan Kejadian KPD di R. Bersalin RSUD Dr. Adjidarmo Rangkasbitung Tahun 2013

\begin{tabular}{cccccc}
\hline Umu & \multicolumn{2}{c}{ KPD } & Jmlh & P & OR \\
\cline { 2 - 4 }$r$ & Ya & Tidak & & & $\begin{array}{c}(\mathrm{CI} \\
95 \%)\end{array}$ \\
\cline { 2 - 4 }$\leq 27$ & 328 & 244 & 572 & & \\
thn & $(63,3 \%)$ & $(47,1 \%)$ & $(55,2 \%)$ & & 1,939 \\
$>27$ & 232 & 232 & 464 & 0,000 & $(1,512$ \\
thn & $(36,7 \%)$ & $(52,9 \%)$ & $(44,8 \%)$ & & - \\
\hline Jmlh & 518 & 518 & 1036 & & $2,485)$ \\
& $(100,0 \%)$ & $(100,0 \%)$ & $(100,0 \%)$ & & \\
\hline
\end{tabular}

Secara deskriptif table 7 menunjukkan bahwa kelompok ibu bersalin yang berusia kurang atau sama dengan 27 (duapuluh tujuh) tahun lebih banyak $(63,3 \%)$ yang mengalami KPD dari pada yang tidak mengalami KPD hanya $(47,1 \%)$. Sebaliknya kelompok ibu bersalin yang berusia lebih dari 27 (dua puluh tujuh) tahun lebih banyak $(52,9 \%)$ yang tidak mengalami KPD dari pada yang mengalami KPD hanya $36,7 \%$.

Sedangkan secara bivariat diperoleh nilai $\mathrm{p}$ sebesar $0,000(\mathrm{p}<\alpha)$ yang berarti bahwa terdapat hubungan bermakna secara statistic antara umur ibu dengan kejadian KPD; dengan nilai OR sebesar 1,939 yang berarti bahwa ibu bersalin dengan usia kurang atau sama dengan 27 (dua puluh tujuh) tahun berisiko hamper dua kali lebih besar untuk mengalami KPD bila dibandingkan dengan ibu bersalin yang berumur lebih dari 27 (dua puluh tujuh) tahun.

\section{Umur Kehamilan dan Kejadian} KPD pada Ibu Bersalin

Tabel 8

Distribusi Frekuensi Ibu Hamil Berdasarkan Umur Kehamilan dan Kejadian KPD di R. Bersalin

RSUD Dr. Adjidarmo Rangkasbitung Tahun

\begin{tabular}{|c|c|c|c|c|}
\hline \multirow{2}{*}{$\begin{array}{c}\text { Umur } \\
\text { Kehamilan }\end{array}$} & \multicolumn{2}{|c|}{ KPD } & \multirow[t]{2}{*}{ Jmlh } & \multirow[t]{2}{*}{$\mathrm{P}$} \\
\hline & $\mathrm{Ya}$ & Tidak & & \\
\hline Tdk & 119 & 134 & 253 & \\
\hline Aterm & $(23,0 \%)$ & $(25,9 \%)$ & $(24,4 \%)$ & \\
\hline \multirow[t]{2}{*}{$>27$ tahun } & 399 & 384 & 783 & 0,311 \\
\hline & $(77,0 \%)$ & $(74,1 \%)$ & $(75,6 \%)$ & \\
\hline \multirow[t]{2}{*}{ Jumlah } & 518 & 518 & 1036 & \\
\hline & $(100,0 \%)$ & $(100,0 \%)$ & $(100,0 \%)$ & \\
\hline
\end{tabular}

Secara deskriptif table 8 menunjukkan bahwa kejadian KPD dan ketidakjadian KPD pada masingmasing kelompok ibu bersalin berdasarkan umur kehamilan, proporsinya hampir sama, sehingga secara bivariat diperoleh nilai $p$ sebesar $0,311(\mathrm{p}>\alpha)$ yang berarti bahwa secara statistic tidak terdapat 
hubungan bermakna antara umur kehamilan ibu bersalin dengan kejadian KPD.

3. Paritas dan Kejadian KPD pada Ibu Bersalin

Tabel 9

Distribusi Frekuensi Ibu Hamil Berdasarkan Paritas dan Kejadian KPD di R. Bersalin RSUD Dr. Adjidarmo Rangkasbitung Thn 2013

\begin{tabular}{|c|c|c|c|c|c|}
\hline \multirow[t]{3}{*}{ Paritas } & \multicolumn{2}{|c|}{ KPD } & \multirow[t]{3}{*}{ Jmlh } & \multirow[t]{3}{*}{$\mathrm{P}$} & OR \\
\hline & \multirow[t]{2}{*}{$\mathrm{Ya}$} & \multirow[t]{2}{*}{ Tidak } & & & (CI \\
\hline & & & & & $95 \%)$ \\
\hline \multirow{6}{*}{ Multi/Grnde } & 326 & 207 & 533 & \multirow{9}{*}{0,00} & \\
\hline & $(62,9$ & $(40,0$ & $(51,4$ & & 2,551 \\
\hline & $\%)$ & $\%)$ & $\%)$ & & $(1,986$ \\
\hline & 192 & 311 & 503 & & $3,277)$ \\
\hline & $(37,1$ & $(60,0$ & $(44,8$ & & \\
\hline & $\%)$ & $\%)$ & $\%)$ & & \\
\hline \multirow[t]{3}{*}{ Jumlah } & 518 & 518 & 1036 & & \\
\hline & $(100,0$ & $(100,0$ & $(100,0$ & & \\
\hline & $\%)$ & $\%)$ & $\%)$ & & \\
\hline
\end{tabular}

Secara deskriptif table 9 menunjukkan bahwa kelompok ibu bersalin yang memiliki paritas 1 (primipara) lebih banyak $(62,9 \%)$ yang mengalami KPD dari pada yang tidak mengalami KPD hanya (40,0\%). Sebaliknya kelompok ibu bersalin yang memiliki paritas lebih dari 1 (multipara atau grandemultipara) lebih banyak $(60,0 \%)$ yang tidak mengalami KPD dari pada yang mengalami KPD hanya $37,1 \%$.
Sedangkan secara bivariat diperoleh nilai $\mathrm{p}$ sebesar $0,000(\mathrm{p}<\alpha)$ yang berarti bahwa terdapat hubungan bermakna secara statistic antara paritas ibu dengan kejadian KPD; dengan nilai OR sebesar 2,551 yang berarti bahwa ibu bersalin primipara berisiko hamper tiga kali lebih besar untuk mengalami KPD bila dibandingkan dengan ibu bersalin multipara atau grandemultipara.

\section{Pekerjaan Ibu dan Kejadian KPD pada Ibu Bersalin}

Tabel 10

Distribusi Frekuensi Ibu Bersalin Berdasarkan Pekerjaan Ibu dan Kejadian KPD di R. Bersalin RSUD Dr. Adjidarmo Rangkasbitung Tahun 2013

\begin{tabular}{ccccc}
\hline Bkrja & \multicolumn{2}{c}{ KPD } & Jumlah & P \\
\cline { 2 - 3 } & Ya & Tdk & & \\
\hline Ya & 52 & 56 & 108 & \\
& $(10,0 \%)$ & $(10,8 \%)$ & $(10,4 \%)$ & \\
Tidak & 464 & 464 & 928 & 0,760 \\
& $(90,0 \%)$ & $(89,2 \%)$ & $(89,6 \%)$ & \\
\hline Jmlh & 518 & 518 & 1036 & \\
& $(100,0 \%)$ & $(100,0 \%)$ & $(100,0 \%)$ & \\
\hline
\end{tabular}

Secara deskriptif table 10 menunjukkan bahwa kejadian KPD dan ketidakjadian KPD pada masingmasing kelompok ibu bersalin berdasarkan pekerjaan, proporsinya hamper sama, sehingga secara bivariat diperoleh nilai $\mathrm{p}$ sebesar 
$0,760(\mathrm{p}>\alpha)$ yang berarti bahwa secara statistic tidak terdapat hubungan bermakna antara pekerjaan ibu bersalin dengan kejadian KPD.

5. Pekerjaan Suami dan Kejadian KPD pada Ibu Bersalin

Tabel 11

Distribusi Frekuensi Ibu Bersalin Berdasarkan Pekerjaan Suami dan Kejadian KPD di R. Bersalin RSUD Dr. Adjidarmo Rangkasbitung Tahun 2013

\begin{tabular}{ccccc}
\hline \multirow{2}{*}{$\begin{array}{c}\text { Pekerja } \\
\text { an }\end{array}$} & Ya & Tidak & $\mathrm{p}$ \\
\cline { 2 - 4 } & 309 & 324 & 633 & \\
\hline Buruh & $(59,7 \%)$ & $(62,5 \%)$ & $(61,1 \%)$ & \\
& 209 & 194 & 403 & 0,372 \\
Bukan & $(40,3 \%)$ & $(37,5 \%)$ & $(38,9 \%)$ & \\
Buruh & 518 & 518 & 1036 & \\
\hline Jumlah & $(100,0 \%)$ & $(100,0 \%)$ & $(100,0 \%)$ & \\
\hline
\end{tabular}

Secara deskriptif table 11 menunjukkan bahwa kejadian KPD dan ketidakjadian KPD pada masingmasing kelompok ibu bersalin berdasarkan pekerjaan suami, proporsinya hamper sama, sehingga secara bivariat diperoleh nilai $p$ sebesar $0,372(p>\alpha)$ yang berarti bahwa secara statistic tidak terdapat hubungan bermakna antara pekerjaan suami ibu bersalin dengan kejadian KPD.

\section{Pembahasan}

1. Hubungan Umur Ibu dengan Kejadian KPD

Hasil analisis secara deskriptif menunjukkan bahwa kelompok ibu bersalin yang berusia kurang atau sama dengan 27 (duapuluh tujuh) tahun lebih banyak $(63,3 \%)$ yang mengalami KPD dari pada yang tidak mengalami KPD hanya $\quad(47,1 \%) . \quad$ Sebaliknya kelompok ibu bersalin yang berusia lebih dari 27 (dua puluh tujuh) tahun lebih banyak $(52,9 \%)$ yang tidak mengalami KPD dari pada yang mengalami KPD hanya 36,7\%.

Begitu pula hasil analisis secara bivariat menunjukkan bahwa nilai $\mathrm{p}$ yang diperoleh sebesar 0,000 $(p<\alpha)$ yang berarti bahwa terdapat hubungan bermakna secara statistic antara umur ibu dengan kejadian KPD; dengan nilai OR sebesar 1,939 yang berarti bahwa ibu bersalin dengan usia kurang atau sama dengan 27 (dua puluh tujuh) tahun berisiko hamper dua kali lebih besar untuk mengalami KPD bila dibandingkan dengan ibu bersalin yang berumur lebih dari 27 (dua puluh tujuh) tahun. 
Hasil tersebut memberikan arti bahwa ibu bersalin dengan usia muda ( $\leq 27$ tahun) memiliki potensi yang lebih besar untuk mengalami KPD bila dibandingkan dengan ibu bersalin yang berusia $>27$ tahun. Hal itu dapat disebabkan bahwa para ibu muda (pasangan muda) masih memiliki keinginan seks (berhubungan badan) yang tinggi, sehingga berpotensi kurang mengabaikan keadaan kandungannya yang dapat berakibat pecahnya ketuban sebelum waktunya. Pernyataan tersebut sesuai dengan yang dinyatakan oleh Ahmadi (1998) bahwa manusia dilengkapi dengan nafsu untuk melakukan "kawin" (berhubungan badan) yang akan berkembang sesuai dengan bertambahnya usia. Pada saat manusia berusia muda setelah melewati masa puber atau masuk pada masa remaja, keinginan seks menjadi meningkat.

Disamping itu, karena pasangan muda memiliki kecenderungan "semangat" yang tinggi dalam melakukan hubungan suami istri, maka keadaan tersebut seringkali tidak memperhatikan prosedur atau tahapan hubungan suami istri yang seharusnya, sehingga berpotensi terjadinya hal-hal yang tidak diinginkan. Nugraha (2010) menyatakan bahwa hubungan seks yang memberikan kenikmatan harus dilakukan dengan kasih saying dan diawali dengan adanya fore play, sehingga tidak berakibat buruk terhadap suami istri, terutama pihak istri.

Selanjutnya Nugraha (2010) menyatakan bahwa for play sebelum melakukan hubungan suami istri sangat dibutuhkan, karena dengan for play otot-otot reproduksi menjadi lemas/lentur, bahkan kemaluan wanita mengeluarkan lender sebagai tanda bahwa dia telah siap "dipakai"

Dari penjelasan tersebut, mengartikan bahwa hubungan seks suami istri harus dilakukan dengan hati-hati apalagi bila istri sedang dalam keadaan hamil. Walaupun nafsu mengggebu, tetapi tahapan untuk melakukan hubungan seks tersebut tetap harus mengikuti prosedur yang seharusnya, sampai keadaan tubuh istri siap untuk melakukannya. Dengan kehati-hatian dan kesiapan tersebut dapat 
mengurangi bahkan terhindar dari hal-hal yang tidak diinginkan akibat hubungan suami istri, seperti terjadinya ketuban pecah dini.

2. Hubungan Paritas dengan Kejadian KPD

Hasil analisis secara
deskriptif menunjukkan bahwa
kelompok ibu bersalin yang memiliki paritas 1 (primipara) lebih banyak $(62,9 \%)$ yang mengalami KPD dari pada yang tidak mengalami KPD hanya $(40,0 \%)$ Sebaliknya kelompok ibu bersalin yang memiliki paritas lebih dari 1 (multipara atau grandemultipara) lebih banyak $(60,0 \%)$ yang tidak mengalami KPD dari pada yang mengalami KPD hanya $37,1 \%$.

Keadadaan pada hasil analisis secara deskriptif sejalan dengan hasil analisis secara bivariat yang memperoleh nilai $\mathrm{p}$ sebesar $0,000(\mathrm{p}$ $<\alpha$ ) yang berarti bahwa terdapat hubungan bermakna secara statistic antara paritas ibu dengan kejadian KPD; dengan nilai OR sebesar 2,551 yang berarti bahwa ibu bersalin primipara berisiko hamper tiga kali lebih besar untuk mengalami KPD bila dibandingkan dengan ibu bersalin multipara atau grandemultipara.

Hasil uji hubungan antar kedua variable inipun (antara paritas dengan kejadian KPD) memberikan makna yang sama dengan penjelasan sebelumnya (antara umur dengan kejadian KPD); bahwa pada paritas 1 (primipara) kecenderungannya bahwa pasangan tersebut merupakan pasangan muda (hamil yang pertama), sehingga keinginan untuk melakukan hubungan seks antar suami istri masih sangat tinggi, yang mungkin bias jadi tidak mengenal waktu dan frekuensi melakukannya.

Hubungan seks suami istri memang tidak dilarang, tetapi semua itu harus dilakukan sesuai dengan yang seharusnya dan tetap memperhatikan hal-hal tertentu, terutama pada saat istri dalam keadaan hamil. Hubungan seks antar suami istri yang tidak memperhatikan aturan (terutama suami), sebenarnya hanya berorientasi pada penyaluran nafsu belaka. Gunawan (1993) menyatakan bahwa seks yang diartikan dengan 
persetubuhan antara lain dapat berupa untuk menyalurkan kesenangan saja.

Oleh karena itu, supaya hubungan seks dapat dinikmati oleh kedua belah pihak (suami maupun istri), maka perlu diingat bahwa "pemanasan" sebelum melakukan seks itu adalah penting terutama untuk istri; karena bagi perempuan hubungan seks yang dapat memberikan kenikmatan adalah hubungan yang dilakukan atas dasar suka sama suka dan keadaan tubuhnya sudah siap untuk melakukan itu, sehingga dampak melakukan hubungan suami istri menjadi positif, terutama untuk istri terlebih sedang dalam keadaan hamil. Nugraha (2010) menyatakan bahwa bila seorang wanita melakukan penolakan terhadap hubungan seks (termasuk pada suaminya), maka dapat menyebabkan otot-otot tubuh si wanita, termasuk otot pinggang dan kemaluannya bereaksi menolak, yang berakibat otot-otot tersebut menjadi kaku.

Kekakuan otot-otot tersebut pada saat seorang wanita melakukan hubungan badan dengan suaminya dapat berakibat robekan pada otot vagina, atau pada wanita/istri yang sedang hamil, tidak menutup kemungkinan dapat menyebabkan terjadinya pecah ketuban sebelum waktunya. Untuk itu, supaya tidak terjadi hal demikian, maka Nugraha (2010) menyatakan bahwa suami istri dalam melakukan hubungan badan, harus ada kesediaan dari kedua belah pihak, kemudian sebelum melakukan hubungan seks suami istri perlu melakukan for play yang dapat berdampak terhadap kelemasan/relaksasi otot-otot wanita/istri termasuk otot kemaluannya, dan kemaluan istri mengeluarkan lender sebagai pelican yang menandakan bahwa alat reproduksi istri sudah siap untuk melakukan hubungan seks dengan suaminya.

3. Hubungan Umur Kehamilan, Pekerjaan Ibu dan Pekerjaan Suami dengan Kejadian KPD

Hasil analisis secara deskriptif anatara pekerjaan ibu hamil dengan kejadian KPD 
menunjukkan bahwa kejadian KPD dan ketidakjadian KPD pada masingmasing kelompok ibu bersalin berdasarkan pekerjaan, proporsinya hamper sama, sehingga secara bivariat diperoleh nilai $\mathrm{p}$ sebesar $0,760(p>\alpha)$ yang berarti bahwa secara statistic tidak terdapat hubungan bermakna antara pekerjaan ibu bersalin dengan kejadian KPD. Keadaan tersebut juga terjadi pada analisis hubungan antara pekerjaan suami dengan kejadian KPD pada ibu bersalin, yang menunjukkan bahwa kejadian KPD dan ketidakjadian KPD pada masingmasing kelompok ibu bersalin berdasarkan pekerjaan suami, proporsinya hamper sama, sehingga secara bivariat diperoleh nilai $p$ sebesar $0,372(p>\alpha)$ yang berarti bahwa secara statistic tidak terdapat hubungan bermakna antara pekerjaan suami ibu bersalin dengan kejadian KPD. Sejalan pula dengan hasil analisis bivariat antara umur kehamilan dengan kejadian KPD, diperoleh informasi secara deskriptif bahwa kejadian atau ketidakjadian KPD hamper sama besar pada kelompok ibu bersalin yang dilihat berdasarkan umur kehamilan; dengan nilai $\mathrm{p}$ sebesar $0,311(\mathrm{p}>\alpha)$, yang berarti bahwa secara statistic tidak terdapat hubungan bermakna antara umur kehamilan dengan kejadian KPD.

Dari hasil analisis tersebut menunjukkan bahwa ketiga variable (umur kehamilan, pekerjan ibu, dan pekerjaan suami ibu) yang diduga berpengaruh terhadap kejadian KPD, ternyata tidak terbukti. Hal itu memberikan arti bahwa umur kehamilan, pekerjaan ibu, dan pekerjaan suami tidak berpotensi untuk berpengaruh terhadap kejadian KPD pada ibu hamil. Keadaan tersebut dapat disebabkan karena pekerjaan ibu selama hamil tidak termasuk ke dalam jenis pekerjaan yang berat dan melelahkan, sehingga kondisi fisik ibu relative masih bias bertahan dengan kehamilannya walaupun ibu memiliki pekerjaan tertentu. Dengan demikian pekerjaan ibu dan pekerjan suami ibu bersalin tidak dapat dijadikan sebagai predictor untuk kejadian KPD.

Wiknjosastro menyatakan bahwa keadaan fisik ibu yang sehat/baik, sangat berpengaruh 
terhadap keadaan kehamilan ibu. Untuk menjaga agar fisik ibu tetap baik, maka dibutuhkan intake makanan yang cukup dan hindarkan dari kelelahan fisik. Pada bagian lain Varney (2008) menyatakan bahwa KPD dapat terjadi dan meningkat risikonya pada ibu hamil yang mengalami kelelahan fisik akibat keletihan bekerja pada saat kehamilan belum cukup bulan. Dengan demikian walaupun ibu hamil melakukan aktifitas pekerjaan secara rutin, tetapi makanan tetap terpenuhi dan ibu tidak mengalami kelelahan, maka kehamilan akan tetap terjaga.

Demikian pula pekerjaan suami, yang diasumsikan bahwa para suami yang bekerja sebagai buruh kasar, sopir, tukang ojek, dan sejenisnya berkecenderungan memiliki perilaku yang kurang menunjang terhadap kelangsungan kehamilan istrinya, seperti melakukan hubungan badan dengan istrinya yang sedang hamil tanpa mempertimbangkan kemungkinan terjadinya komplikasi kehamilan dan persalinan yang mungkin terjadi pada istri dan janinnya; yang diakibatkan karena kurangnya pengetahuan mereka terhadap kesehatan khususnya yang berkaitan dengan ibu hamil.

Syafrudin dan Yudhia Fratidhina (2009) menyatakan bahwa perilaku merupakan hasil dari berbagai factor baik internal maupun eksternal, antara lain factor yang mempengaruhinya adalah factor pengetahuan. Dengan demikian dapat dijelaskan bahwa perilaku seseorang terhadap sesuatu dapat menggambarkan pengetahuannya terhadap sesuatu tersebut. Akan tetapi hasil penelitian ini menunjukkan bahwa pekerjaan suami yang diasumsikan berkorelasi dengan pengetahuan suami, tidak terbuktikan. Suami yang memiliki pekerjaan kasar seperti sopir/buruh/tukang ojeg tidak selalu memiliki pengetahuan yang rendah tentang bagaimana harus memperlakukan istri yang sedang hamil pada saat melakukan hubungan suami istri.

Begitu pula dengan umur kehamilan; variable ini tidak dapat dijadikan sebagai predictor terhadap kejadian KPD. Selama keadaan fisik 
ibu baik, tidak terdapat kelainan darah, dan kantung ketuban cukup baik, maka kejadian KPD tidak akan terjadi. Saifudin (2010) menyatakan bahwa pecahnya selaput ketuban dapat terjadi pada kehamilan preterm sebelum kehamilan 37 minggu maupun kehamilan aterm. Di sisi lain Nugroho (2010) menyatakan bahwa meskipun factor penyebab terjadinya KPD masih sulit diketahui, namum beberapa factor predisposisi yang dapat diidentifikasi penyebab KPD ialah infeksi, golongan darah ibu dan anak tidak sesuai, multigrafida, merokok, defisiensi gizi khususnya vitamin C, servik yang tidak inkopeten, polihidramnion, riwayat KPD sebelumnya, kelainan selaput ketuban, tekanan intra uterin yang meninggi atau overdistesi, trauma, kelainan letak.

Dengan demikian selama tidak ada kelainan pada fisik ibu, dan selaput ketuban, maka ketuban pecah dini tidak akan terjadi; serta kejadian ketuban pecah dini itu dapat terjadi pada ibu beralin dengan usia cukup bulan maupun belum cukup bulan, dengan kata lain usia kehamilan (aterem maupun preterem) tidak berpengaruh terhadap kejadian KPD pada ibu bersalin.

\section{Simpulan}

Dari hasil analisis yang dilakukan, maka ada beberapa simpulan yang dapat dikemukan, yaitu:

1. Masih banyak terdapat kejadian ketuban pecah dini pada ibu bersalin yang terdaftar dalam buku register ibu bersalin di Ruang Bersalin RSUD Dr. Adjidarmo RangkasbitungLebak.

2. Lebih dari sebagian ibu bersalin memiliki usia kurang atau sama dengan 27 tahun; dan masih banyak ibu bersalin yang usia kehamilannya belum cukup bulan.

3. Lebih dari sebagian ibu bersalin memiliki paritas satu (primipara).

4. Masih terdapat sebagian kecil ibu bersalin yang memiliki pekerjaan tetap; dan sebagian besar suami ibu bersalin memiliki pekerjaan 
sebagai buruh kasar (sopir/tukang

ojek/buruh pabrik/tani)

5. Umur dan paritas ibu bersalin memiliki hubungan bermakna dengan kejadian ketuban pecah dini.

6. Umur kehamilan, pekerjaan ibu, dan pekerjaan suami ibu bersalin tidak memiliki hubungan bermakna dengan kejadian ketuban pecah dini.

\section{Daftar Pustaka}

Ahmadi, Abu (1998). Psikologi Umum. Cetakan kedua. Jakarta: PT. Rineka Cipta

Cuningham, F.G (2006). Obstetri William, Jakarta : EGC

Gunawan, FX Rudi (1993). Filsafat Seks. Cetakan pertama. Yogyakarta: PT Bentang Intervisi Utama.

Nugraha, Boyke Dian (2010). Di Balik Ruang Praktik Dr. Boyke. Cetakan pertama. Jakarta: PT Bumi Aksara.

Prawirohardjo,Sarwono (2010), Ilmu Kebidanan, Jakarta : PT Bina Pustaka Sarwono Prawirohardjo
Saefudin, Abdul Bari. dkk (2010), Buku Panduan Praktis Pelayanan Kesehatan Maternal dan Neonatal, Jakarta : PT Bina Pustaka Sarwono Prawirohardjo

Sualma, K. 2009. Penatalaksanaan Ketuban Pecah Dini. http//www.medicastore. diunduh 24 Maret 2014

Syafrudin dan Yudhia Fratidhina (2009). Promosi Kesehatan untuk Mahasiswa Kebidanan. Cetakan pertama. Jakarta: CV Trans Info Media.

Varney, Helen. Kriebs, Jan M. Gegor, Carolyn L (2007), Buku Ajar Asuhan Kebidanan, Edisi 4, Volume 2, Jakarta : EGC

Wiknjosastro, Hanifa (1994). Ilmu Kebidanan. Edisi kedua. Jakarta: Yayasan Bina Pustaka Sarwono Prawirohardjo. 